\section{Arising Sales force Motivation Due to Organizational Justice}

\author{
Sheikh Raheel Manzoor \\ Lecturer, Institute of Management Sciences, Kohat University of Science \& Technology, \\ Kohat, KPK- Pakistan \\ E-mail: Raheel_manzoor2000@yahoo.com
}

\begin{abstract}
Ahmer Naveed
Lecturer, Institute of Management Sciences, Kohat University of Science \& Technology, Kohat, KPK- Pakistan
\end{abstract}

Syed Habib Shah

Lecturer, Institute of Management Sciences, Kohat University of Science \& Technology, Kohat, KPK- Pakistan

Accepted: April 9, 2012 Published: June 17, 2012

Doi:10.5296/ijld.v2i3.1958ＵRL: http://dx.doi.org/10.5296/ijld.v2i3.1958

\begin{abstract}
This research study analyzes the effect of organizational justice (PJ, DJ) on Independent Sale Personnel's (ISP's) motivation. This study was cross sectional and self administered questionnaires were distributed among the sale personnel of International Brands Private Limited (IBL), Company Pakistan. Total five branches of IBL, Pakistan were taken for data collection i.e. Karachi, Lahore, Islamabad, Peshawar and Kohat. In order to investigate the relationship between Organizational justice (i.e. procedural justice and distributive justice) and ISP's motivation regression and correlation techniques were used. The result of the study suggests that there is a significant positive impact of predictors on the response variable.
\end{abstract}

Keywords: Organizational justice (procedural justice, distributive justice), ISP's motivation. 


\section{Introduction}

Organizational justice (or fairness) is a significant subject in explaining employees' performances within the organization. It is evident from literature that organizational justice performs an important role in explaining employees' attitudes and behaviour (Choi, 2008). The impact of organizational justice on work outcome such as job satisfaction, organizational commitment and turnover intentions are clearly documented by the research literature (Williams, McDaniel \& Nguyen, 2006). However, extensive searches of sales and non sales literature investigated the impact of organizational justice on employees' motivation. Distributive justice (DJ) and procedural justice (PJ) are the two categories of organizational justice (Greenberg, 1990; Konovsky, 2000). Perceived fairness of the outcomes (e.g. pay, status) comes under distributive justice; whereas PJ deals with the perceived fairness of the processes that eventually leads to the outcomes (Greenberg, 1990). Motivation and performance are most important issues for all types of Independent Sale Personnel (ISP's) management (Tyagi \& Wotruba, 1998). By using the proper and fair organizational justice (PJ, DJ) within the organization have multiple benefits for organizations like increase in ISP's motivation, job performance, pay satisfaction, productivity, and workers efficiency. Therefore many organizations uses fair organizational justice for the smooth functioning of organizational tasks (Tyagi \& Wotruba, 1998).

In Pakistan a very small number of researches were conducted to identify the effects as well relation between organizational justice and ISP's motivation. Therefore, the objectives of this research study are to find out the impact of organizational justice (PJ, DJ) on ISP's motivation and also to find out the relationship between organizational justice (PJ, DJ) and ISP's motivation. To meet the objectives of the research study the data was collected from four branches of the International Brand Limited (IBL) Company Pakistan. The IBL Group is a diversified business house engaged in a wide range of business activities in Pakistan including international trading, local manufacturing, marketing, sales and distribution of various products and financial services. In mid 80s the Group management decided to diversify into manufacturing by creating strategic partnerships with some of the companies for which it had provided distribution services. As a result the ownership and management of the group companies was divided into two sub groups known as IBL Group. In 1991 a new company by the name of International Brands (Private) Limited was formed. All the marketing and distribution business of consumer goods of the Group was moved under the banner of IBL and since then the Company has focused on consumer products marketing and distribution. The IBL business departments in Pakistan are Gillette, Proctor \& Gamble, Searle Pharma \& Consumer, Shezan and Telecom. This research study is based on quantitative research technique. The organizational justice (PJ, DJ) is taken in this study as an independent variable (I.V's) whereas (ISP's) motivation is taken as a dependent variable (D.V). This study also seeks to answer the gap between justice and motivation literature by examining how justice may affect ISP's motivation. This research study highlights the importance of organizational justice and its effects on ISP's motivation within the organizations of Pakistan. 


\section{Literature Review}

\subsection{Organizational Justice \& Sales force Motivation}

It is evident from the research literature that distributive justice (DJ) and procedural justice (PJ) are the two main kinds of organizational justice (Greenberg, 1990; Konovsky, 2000). Perceived fairness of the outcomes (e.g. pay, status) comes under distributive justice; whereas PJ deals with the perceived fairness of the processes that eventually leads to the outcomes (Greenberg, 1990). According to Adams' $(1963,1965)$ theory, employees are being judged on their own inputs like time and effort and are compared with their own outputs like pay and status, as to be treated justifiably or unjustifiably. As a result, employees are either satisfied or dissatisfied resulting in low or high performance and motivation (Mowday \& Colwell, 2003). Refereeing to cognition theory (Folger, 1977) argue that outcome (DJ) and procedure (PJ) correlate in a way to create a sense of overall justice or injustice within the organization. Relationship between justice perceptions and motivation is so far investigated by very few empirical studies. As stated earlier, justice perceived would eventually lead into the motivation of the sale force if there own inputs that is time and efforts are rated justifiably. Findings from these limited studies along with the advancement in conceptual development strengthen the proposition that motivation and justice have been overlooked both in sales and non-sales research (Locke \& Latham, 2004). More specifically, motivation has long been viewed as a central role in performance (Barrick, Stweart \& Piotrowski, 2002). According to Ambrose and Kulik's (1999) there is a gap of empirical knowledge explaining how motivation can be directly related to performance. Given that much research from non-sales literature has already documented the impact of justice on job performance and pay satisfaction (Haq, Iqbal \& Rehman, 2008). It is evident from the research that there is direct impact of justice perceptions on sales peoples' motivation, and the indirect impact of justice perceptions on sales peoples' performance and pay satisfaction via motivation. The traces of these relationships can be found in Adams' $(1963,1965)$ equity theory and Porter and Lawler's (1968) work motivation model. The relationships, according to equity theory can be described as: Outcomes which are unfair (e.g. pay, status) motivates the employees to rectify the unfair situation if they are not happy with these outcomes, however behavioural reaction that could be taken into account which could reduce their inputs or performance level (Farmer, Beehr \& Love, 2003).

It has been clearly stated by number of significant studies that there is positive effect of justice perceptions on pay satisfaction (DeConinck \& Stilwell, 2004). On other hand there are few studies which yet indicate the importance of justice in predicting employee's motivation and job performance (Zeffane \& Zarooni, 2008). According to Tyagi's (1990) specifically in sale research study of insurance salespeople found that their perception of money unfairness had a strong unpleasant effect on extrinsic motivation, and similarly recognition unfairness had the significant negative effect on intrinsic motivation of salespeople. According to Dubinsky and Levy (1989) fairness perception of pay administration has positive effect on retail salespeople's motivation. However, none of the study included performance in investigation. Based on the preceding literature discussion above, the following hypotheses are proposed. $\mathbf{H}_{\mathbf{1}}$. PJ has significant positive effect on ISP's motivation. 
$\mathbf{H}_{2}$. DJ has significant positive effect on ISP's motivation.

\subsection{Conceptual Framework}

The conceptual framework of the study is as follows namely, PID model.

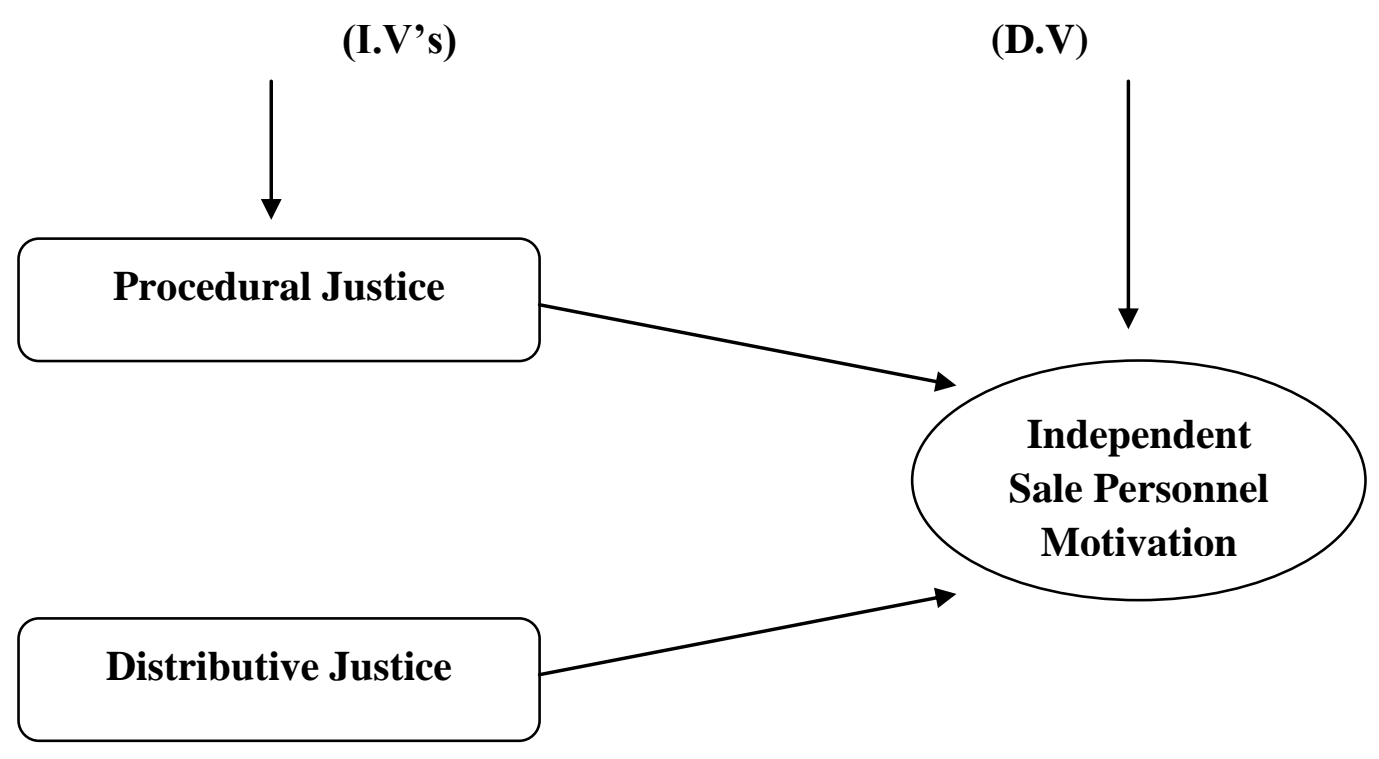

\section{Research Methodology}

This research study was conducted to investigate the effect of organizational justice (PJ, DJ) on ISP's motivation. The data was collected through random distribution of questionnaire among the staff members of IBL Company Pakistan. Five branches of IBL Company Pakistan were taken for data collection these are Karachi, Lahore, Islamabad, Peshawar and Kohat. The research study was cross sectional, research technique was quantitative and the unit of analysis was individual. The main focus of the distribution questionnaire was to measure the motivation of sale personnel of IBL Pakistan. The Statistical Package for Social Sciences (SPSS) version 16.0 was used for the statistical analysis. For the analysis of the organizational justice (PJ, DJ) and ISP's motivation, firstly, descriptive analysis were measured and then correlation, regression was calculated between (IV's) and (D.V).

\subsection{Questionnaire:}

The instruments used to gather the data was questionnaire. The questionnaire items of this research study were taken from the study of (Niehoff \& Moormon, 1993; Price \& Mueller, 1986; Kovach, 1987). Five items of procedural justice were adopted from Niehoff \& Moormon (1993) which focuses on the employee perception of procedural justice. Five items of distributive justice were taken from the study of (Price \& Mueller, 1986) and five items to measure the ISP's motivation were taken from (Kovach, 1987). The reliability and validity of the questionnaire items were re-examined and found to be good. The questionnaire consists of 2 parts with section " $A$ " and section "B". Section "A" consisted of item seeking demographic data such as age, gender and management level with no score attached to it. Section "B" consists of the items, which collect information about the procedural justice, distributive 


\section{Al Macrothink}

justice (I.V's) and its effects on ISP's motivation (D.V). Section "B" of the questionnaire measured on five point Likert scale ranging from ( $1=$ strongly disagree to $5=$ strongly agree).

\subsection{Population}

The population for this study was comprised on upper, middle and lower management sale personnel of IBL, Pakistan. From five branches of IBL, Pakistan, data was collected from the branches of Khyber Pakhtunkhwa (KPK), Punjab and Sindh, Provinces of Pakistan and one branch from capital city Islamabad. Two branches were taken from KPK i.e. Peshawar and Kohat, one branch from Punjab i.e. Lahore, one from Sindh i.e. IBL Head Office Karachi and one from Islamabad. Total sale personnel in Karachi, Lahore, Islamabad, Peshawar and Kohat branches were 50, 25, 20, 15 and 6 respectively. Total population consisted of 116 staff members which taken part in this survey study.

\subsection{Sample Design}

The total 116 questionnaires were distributed among the sale personnel of IBL, Company Pakistan. In IBL, Karachi Head Office 50 questionnaires were randomly distributed among the sale personnel and 50 usable questionnaires were returned, giving a response rate of $100 \%$. In IBL, Karachi Head Office 48 respondents are male and 2 respondents are female. In IBL, Lahore branch, total 25 questionnaires were randomly distributed among the sale personnel and 20 usable questionnaires were returned giving a response rate of $80 \%$. The male respondents were 19 and female respondents were 01. In IBL, Islamabad, total 20 questionnaires were randomly distributed among the sale personnel and 20 usable questionnaires were returned giving a response rate of $100 \%$. The male respondents were 20 , all the respondents were male. In IBL, Peshawar and Kohat 15 and 06 questionnaires were distributed respectively and response rate was $100 \%$. All the respondents were male in Peshawar and Kohat Branches. Total 111 usable questionnaires were returned out of 116, on scrutiny, giving a response rate of $95.6 \%$ which is termed as good. The final sample consists of 111 staff members including male and female of IBL, Company Pakistan. The Male represents 108 of the total sample 111 which shows $97.2 \%$, and Female represents 3 of the total sample 111 which represents $2.7 \%$. There were more men than women in the sample. 


\section{Data, Presentation, Analysis \& Interpretation}

In the analysis section firstly, descriptive statistics of demographic variables were measured and then correlation and regression was calculated between (I.V's) and (D.V).

Table 1

Age * Gender Cross tabulation

\begin{tabular}{|c|c|c|c|c|}
\hline \multicolumn{2}{|c|}{ Count } & & & \multirow[b]{3}{*}{ Total } \\
\hline & & \multicolumn{2}{|c|}{ Gender } & \\
\hline & & Male & Female & \\
\hline \multirow[t]{3}{*}{ Age } & $20-28$ & 47 & 1 & 48 \\
\hline & 29-39 & 44 & 2 & 46 \\
\hline & 40 and above & 17 & 0 & 17 \\
\hline Total & & 108 & 3 & 111 \\
\hline
\end{tabular}

The above table shows the cross tabulation of age and gender. The age was categorized in 20-28 years, 29-39 years and 40 and above years. The Male represents 108 of the total sample 111 which shows $97.2 \%$, and Female represents 03 of the total sample 111 which represents $2.7 \%$.

\section{Table 2}

Gender * Management Level Cross tabulation

\begin{tabular}{|c|c|c|c|c|c|}
\hline \multicolumn{6}{|l|}{ Count } \\
\hline & & \multicolumn{3}{|c|}{ Management Level } & \multirow[b]{2}{*}{ Total } \\
\hline & & Top & Medium & Low & \\
\hline \multirow[t]{2}{*}{ Gender } & Male & 2 & 5 & 101 & 108 \\
\hline & Female & 0 & 3 & 0 & 3 \\
\hline Total & & 2 & 8 & 101 & 111 \\
\hline
\end{tabular}

The above table shows the cross tabulation of management level and gender of IBL Peshawar. Top level managers include National Sales Manager and Regional Sales Managers of IBL Company. Middle level includes Area Sales Managers of IBL and Low level includes Unit Managers and sales personnel of IBL Company. Top level staff members were 02 in which all were male, out of 111 which represent $1.8 \%$ of the total. Medium level staff members were 08 in which male represents 05 and female represents 03 out of 111 which show $7.2 \%$ of the total. Low level staff members were 101 out of 111 in which all are male which demonstrates $90 \%$ of the total.

Table 3

Descriptive Statistics

\begin{tabular}{|l|l|l|l|l|l|l|}
\hline & & Range & Sum & Mean & $\begin{array}{l}\text { Std. } \\
\text { Deviation }\end{array}$ & Variance \\
\hline
\end{tabular}




\begin{tabular}{|l|l|l|l|l|l|l|}
\hline \hline Age & 111 & 2 & 191 & 1.72 & .716 & .512 \\
Gender & 111 & 1 & 114 & 1.03 & .163 & .027 \\
$\begin{array}{l}\text { Management } \\
\text { Level } \\
\text { Valid N (listwise) }\end{array}$ & 111 & 2 & 321 & 2.89 & .366 & .134 \\
\hline
\end{tabular}

Table 3 shows the descriptive statistic of age, gender and management level.

\section{Table 4}

\section{Reliability Statistics}

\begin{tabular}{|l|l|l|}
\hline Variables & $\begin{array}{l}\text { Cronbach's } \\
\text { Alpha }\end{array}$ & N of Items \\
\hline Procedural Justice & .931 & 05 \\
\hline Distributive Justice & .833 & 05 \\
\hline ISP's Motivation & .942 & 05 \\
\hline
\end{tabular}

Cronbach's alpha shows the Inter-item reliability. The reliability statistics for the different variables are above captioned. According to Sekaran (2003) to delete an item from questionnaire, Cronbach's alphas ranged between $0.790-0.826$. So, reliability values of the three variables demonstrate that there is no any problem of deletion of questionnaire items.

\subsection{Correlation Analysis}

The Pearson correlation finds out between organizational justice (PJ, DJ) and ISP's motivation. The correlation value is lie between -1 and +1 . The value -1 represents negative relationship and +1 represents positive relationship between variables.

\section{Table 4}

\section{Correlations}

\begin{tabular}{|ll|l|l|l|}
\hline & & PJ & $\begin{array}{l}\text { ISP's } \\
\text { Motivation }\end{array}$ & DJ \\
\hline PJ & $\begin{array}{l}\text { Pearson } \\
\text { Correlation }\end{array}$ & 1 & $.861^{* *}$ & $.630^{* *}$ \\
& $\begin{array}{l}\text { Sig. (2-tailed) } \\
\text { N }\end{array}$ & 111 & .000 & .000 \\
& Pearson & $.861^{* *}$ & 1 & 111 \\
\hline ISP's & Correlation & .000 & & $.605^{* *}$ \\
& Sig. (2-tailed) & .000 & 111 \\
\hline DJ & Pearson & $.630^{* *}$ & $.605^{* *}$ & 1 \\
& $\begin{array}{l}\text { Correlation } \\
\text { Sig. (2-tailed) }\end{array}$ & .000 & .000 &
\end{tabular}




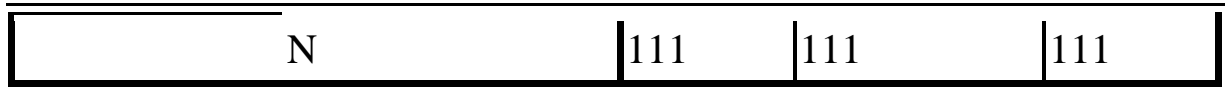

**. Correlation is significant at the 0.01 level (2-tailed).

Table 4 demonstrates the correlation matrix of the employee PJ, DJ and ISP's motivation. Pearson correlation between PJ, DJ and force motivation is positive and highly significant with the values of $.861^{* *}$ and $.630^{* *}$ at 0.01 significance level. This reveal that there is positive relationship exist between (I.V's) and (D.V).

\subsection{Regression Analysis}

The research study uses the multiple regression analysis in order to check out the effect of predictors on response variable. The multiple regression model is as follows:

$Y=\alpha+\beta_{1} X_{1}+\beta_{2} X_{2}+\beta_{3} X_{3}+\beta_{4} X_{4}+\varepsilon$

Where $\mathrm{Y}$ is ISP's motivation (D.V).

$\alpha$ is constant

$\mathrm{X}$ is other factors affecting ISP's motivation

$\beta$ is the regression coefficient which may be positively or negatively affecting (D.V) and (I.V's).

ISP's $M=\alpha+\beta_{1} P J+\beta_{2} \mathrm{DJ}+\varepsilon$

Where ISP's M = Independent Sales Personnel Motivation (D.V) $\quad \beta_{1 \mathrm{PJ}=}$ Procedural Justice $\beta_{2}$ DJ= Distributive Justice (I.V's).

\section{Table 5}

ANOVA ${ }^{b}$

\begin{tabular}{|c|c|c|c|c|c|c|}
\hline \multicolumn{2}{|c|}{ Model } & \multirow{2}{*}{$\begin{array}{ll}\begin{array}{l}\text { Sum } \\
\text { Squares }\end{array} & \text { of } \\
147.883\end{array}$} & \multirow{2}{*}{$\frac{\mathbf{d f}}{2}$} & \multirow{2}{*}{ 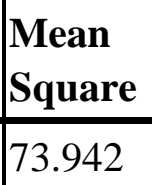 } & \multirow{2}{*}{$\frac{\mathbf{F}}{159.802}$} & \multirow{2}{*}{$\frac{\text { Sig. }}{.000^{\mathrm{a}}}$} \\
\hline 1 & Regression & & & & & \\
\hline & Residual & 49.972 & 108 & .463 & & \\
\hline & Total & 197.856 & 110 & & & \\
\hline
\end{tabular}

a. Predictors: (Constant), DJ, PJ

\section{b. Dependent Variable: ISP's Motivation}

The F-test value is 159.802 and the significance value is $(\mathrm{sig}=.000)$ which is less than $\mathrm{P}<0.05$ which shows the regression model is significant. This further implies that the correlation between dependent variable and independent variables is statistical significant and overall regression model is valid and fit.

\section{Table 6}

\section{Model Summary}

\begin{tabular}{|l|l|l|l|l|}
\hline Model & $\mathbf{R}$ & R Square & $\begin{array}{l}\text { Adjusted } \\
\text { Square }\end{array}$ & $\begin{array}{l}\text { Std. Error of } \\
\text { the Estimate }\end{array}$ \\
\hline 1 & $.865^{\mathrm{a}}$ & .747 & .743 & .680 \\
\hline
\end{tabular}


Model Summary

\begin{tabular}{|l|l|l|l|l|}
\hline Model & $\mathbf{R}$ & $\mathbf{R}$ Square & $\begin{array}{l}\text { Adjusted } \\
\text { Square }\end{array}$ & $\begin{array}{l}\text { Std. Error of } \\
\text { the Estimate }\end{array}$ \\
\hline 1 & $.865^{\mathrm{a}}$ & .747 & .743 & .680 \\
\hline
\end{tabular}

a. Predictors: (Constant), DJ, PJ

Table 6 represents the Regression coefficient ' $R$ ' $=.865$ or $86.5 \%$ which means that correlation between (D.V) and (I.V's) are positive. The coefficient of determination ' $\mathrm{R}^{2,}=.747$ which show that $74.7 \%$ of variation in ISP's motivation is explained by PJ and DJ.

In the above table the regression coefficient for PJ and DJ $\left(\beta_{1}\right)$ and $\left(\beta_{2)}=.796\right.$ and .103 which

Table 7

Coefficients $^{\mathrm{a}}$

\begin{tabular}{|c|c|c|c|c|c|c|c|c|}
\hline \multirow{2}{*}{\multicolumn{2}{|c|}{ Model }} & \multicolumn{2}{|c|}{$\begin{array}{l}\text { Unstandardized } \\
\text { Coefficients }\end{array}$} & \multirow{2}{*}{$\begin{array}{l}\text { Standardized } \\
\text { Coefficients } \\
\text { Beta }\end{array}$} & \multirow[b]{2}{*}{$\mathbf{t}$} & \multirow[b]{2}{*}{ Sig. } & \multicolumn{2}{|c|}{$\begin{array}{l}\text { Collinearity } \\
\text { Statistics }\end{array}$} \\
\hline & & B & Std. Error & & & & Tolerance & VIF \\
\hline \multirow[t]{3}{*}{1} & (Constant) & .264 & .201 & & 1.316 & .191 & & \\
\hline & PJ & .780 & .061 & .796 & 12.774 & .000 & .602 & 1.660 \\
\hline & DJ & .111 & .057 & .107 & 1.941 & .050 & .602 & 1.660 \\
\hline
\end{tabular}

a. Dependent Variable: ISP's Motivation

implies that one percent increase in PJ and DJ increases $79.6 \%$ and $10.3 \%$ in ISP's motivation level if other variables are kept controlled. The T value of PJ and DJ are 12.774 and 1.941 which is significant at .000 and .050 level because significance level is $\mathrm{P}<.05$. This implies that the both the hypotheses of this study are accepted. The hypotheses are PJ has significant positive effect on ISP's motivation and DJ has significant positive effect on ISP's motivation. The above table also demonstrates the multicollinearity statistics. The tolerance value less than 0.20 indicate a multicollinearity problem (O'Brien \& Robert, 2007). In the above table the tolerance values of all (I.V's) are .602 and .602 which shows that the tolerance level is moderate and good. The reciprocal of the tolerance is known as the Variance Inflation Factor (VIF). The VIF 5 to 10 and above indicates the multicollinearity problem (O'Brien \& Robert, 2007). In the above captioned table VIF values of (I.V's) are 1.660 and 1.660 which shows that there is no any problem of multicollinearity. 
Table 8

\section{Collinearity Diagnostics ${ }^{a}$}

\begin{tabular}{|c|c|c|c|c|c|c|}
\hline \multirow{2}{*}{\multicolumn{2}{|c|}{\begin{tabular}{|l} 
Dimensio \\
Model n \\
\end{tabular}}} & \multirow[b]{2}{*}{ Eigenvalue } & \multirow{2}{*}{$\begin{array}{l}\text { Condition } \\
\text { Index }\end{array}$} & \multicolumn{3}{|c|}{\begin{tabular}{|l|} 
Variance Proportions \\
\end{tabular}} \\
\hline & & & & (Constant) & PJ & DJ \\
\hline \multirow[t]{3}{*}{1} & 1 & 2.883 & 1.000 & .01 & .01 & .01 \\
\hline & 2 & .071 & 6.364 & .94 & .30 & .08 \\
\hline & 3 & .045 & 7.966 & .05 & .69 & .91 \\
\hline
\end{tabular}

a. Dependent Variable: ISP's Motivation

The eigen values close to 0 explain little variance. In above table value of 2 and 3 are near to 0 which shows little variance in these variables. The condition index over 15 indicates a possible multicollinearity problem and over 30 suggests a serious multicollinearity problem. In above table values of condition index are in range of 1.00 to 7.966 which reveals that there is no multicollinearity issue between (I.V's) and (D.V).

\section{Discussion, Conclusion, Recommendations \& Future Research Area}

\subsection{Discussion}

This study examines the relationship of organizational justice (PJ, DJ) and ISP's motivation. For obtaining the data, questionnaire was borrowed from the previous studies of (Niehoff \& Moormon, 1993; Price \& Mueller, 1986; Kovach, 1987). Questionnaires were distributed among the sale personnel of IBL, Company Pakistan. The random sampling was done which responded 95.6\%. After screening data, 05 participants were found missing. Over all Cronbach's alpha reliability of the questionnaire items were found (.90) and were good and valid enough for data collection. The descriptive statistics shows that the majority of participants were male with age of early 20's to 40 years and above. The statistical analyses were analyzed through SPSS version 16.0. Hypothesis one states that: Procedural justice has significant positive effect on ISP's motivation and was found significant. The result of the hypothesis one is consistent with the previous study of (Zeffane \& Zarooni, 2008; Tyagi \& Wotruba, 1998). Hypothesis two states that: Distributive justice has significant positive effect on ISP's motivation and was found significant. The result of the hypothesis one is also consistent with the study of (Dubinsky \& Levy, 1989). The overall, regression value of procedural justice, distributive justice and Independent sales personnel was .865 which demonstrates that $86.5 \%$ impact of (I.Vs) on ISP's motivation (D.V) in IBL, Company Pakistan.

\subsection{Conclusion}

The research study found that PJ and DJ have a significant positive effect on ISP's motivation of the IBL, Company Pakistan. The multiple regression model shows the significantly strong relationship between set of 2 independent variables namely procedural justice, distributive justice and dependent variable that is independent sale force motivation. However, procedural justice was found to be the most significant (I.V) having strong relationship with the (D.V) i.e. ISP's motivation. The regression coefficient $\mathrm{R}$ shows the value 0.865 which shows $86.5 \%$ 
proportion of variability between IV's and D.V and coefficient of determination $\mathrm{R}^{2}=.747$ which shows $74.7 \%$ variation in D.V explained by I.V's. The independent variables that are organizational justice (PJ, DJ) explained $79.6 \%$ and $10.7 \%$ of variation respectively towards dependent variable of ISP's motivation. Overall, the results revealed that organizational justice (PJ, DJ) and ISP's motivation were positively correlated. Fair organizational justice (PJ, DJ) was found to be of significant importance if properly implemented. Moreover, organizational justice (PJ, DJ) programs were found to have a positive impact on the ISP's motivation which brings benefits in terms of better organizational performance, higher productivity, competitive advantage and increased employee motivation. Findings of the study also demonstrate that the there is positive correlation exist between (I.V's) and (D.V). Fair organizational justice (PJ, DJ) within the organization is very much beneficial and its effect directly on employee motivation. This might reduce the propensity of employee turnover.

\subsection{Recommendation}

Government should have to adopt and implement fair organizational justice policies in both public and private organizations of Pakistan. Through fair organizational justice (PJ, DJ) employee become motivated and overall organizational productivity and effectiveness can be enhanced. It is significant to build up such an atmosphere where employees are well satisfied. This research study strongly suggests that fair organizational justice (PJ, DJ) must exist in the organizational atmosphere. In this way employees' become motivated and perform better.

\subsection{Future Area for Research}

In future both public and private organization should be analyzed to comprehend some other factors contributing towards sale personnel motivation.

\section{References}

Adams, J. (1963). "Towards an understanding of inequity." Abnormal and Social Psychology, Vol. 67, pp. 422-436.

Adams, J. S. (1965). "Inequity in social exchange. In L. Berkowitz (Ed.), Advances in experimental social psychology”(Vol. 2, pp. 267-299). New York: Academic Press.

Ambrose, M. L., Kulik, C. T. (1999). "Old friends, new faces: Motivation research in the 1990s." Journal of Management, 25(3), 231-292.

Barrick, M. R., Stewart, G. L., \& Piotrowski, M. (2002). "Personality and job performance: test of the mediating effects of motivation among sales representatives." Journal of Applied Psychology, 87(1), 43-51.

Choi, J. (2008). "Event justice perceptions and employees' reactions: perceptions of social entity justice as a moderator." Journal of Applied Psychology, 93(3), 513-528. 
DeConinck, J. B., Stilwell, C. D. (2004). "Incorporating organizational justice, role states, pay satisfaction and supervisor satisfaction in a model of turnover intentions." Journal of Business Research, 57, 225-231.

Dubinsky, A. J., Levy, M. (1989). Influence of organizational fairness on work outcomes of retail salespeople. Journal of Retailing, Vol. 65 Summer (2) pp.221-240.

Farmer, S., Beehr, T., and Love, K. 2003. "Becoming undercover police officers: A note on fairness perceptions, behaviour, and attitudes'. Journal of Organizational Behaviour, 24:373-387.

Folger, R. (1977), 'Distributive and procedural justice: combined impact of 'voice' and improvement on experienced inequity", Journal of Personality and Social Psychology, Vol. 35 No. 1, pp. 108-19.

Greenberg, J.(1990). “Organizational justice: yesterday, today, and tomorrow.” Journal of management, 16(2), 399-432.

Haq, Z., Iqbal, Z., and Rahman, A. (2008). "Job stress among community health workers: a multimethod study from Pakistan", International Journal of Mental Health Systems, 2, (15).

Katzell, R. A., \& Thompson, D. E. (1990). "An integrative model of work attitudes, motivation, and performance." Journal of Human Performance, 3(2), 63-85.

Konovsky, M. A. (2000). "Understanding procedural justice and its impact on business organizations." Journal of Management, 26(3), 489-511.

Kovach, K. A. (1987). "What motivates employees? Workers and supervisors give different answers.” Business Horizons, Volume 30, pp. 58-65.

Locke, E. A., \& Latham, G. P.(2004). "What should we do about motivation theory? Six recommendations for the twenty-first century." Academy of Management Review 29(3), 388-403.

Masterson, S. S., Lewis, K., Goldman, B. M., \& Taylor, M. S. (2000). "Integrating justice and social exchange: the differing effects of fair procedures and treatment on work relationships." Academy of Management Journal, 43(4), 738-748.

Mowday, R. T., \& Colwell, K. A. (2003). "Employee reactions to unfair outcomes in the workplace: The contributions of Adams' equity theory to understanding work motivation." 
Niehoff, B., \& Moorman, R. (1993). "Justice as mediator of the relationship between methods of monitoring and organizational citizenship behaviour." Academy of management Journal, 36(3):527-556

Porter, L. W., Lawler's, E. E. (1968). “Managerial Attitudes and Performance.” Homewood, Illinois Richard D. Irwin, Inc.

Price, J. \& Mueller, C. (1986). Handbook of organizational measurement. Marshfield MA: Pittman.

Sekaran, U. (2003). "Research methods for business: A skill-building approach.” USA, John Willey \& Sons.

Tyagi, P. K. (1990). "Inequities in organizations, salesperson motivation and job satisfaction." International Journal of Research in Marketing, Vol.7, 135-148.

Tyagi, P. K., Wotruba, T. R. (1998). "Do gender and age really matter in direct selling? An exploratory investigation.” Journal of Marketing Management, 8(2), 22-33.

Williams, M. L., McDaniel, M. A., Nguyen, N. T. (2006). "A meta-analysis of the antecedents and consequences of pay level satisfaction." Journal of Applied Psychology, 91(2), 392-413.

Zeffane, R., Al Zarooni, H.A. (2008).'The influence of empowerment, commitment, Job satisfaction and trust on perceived managers' performance'. International journal of Business excellence, 1, (1/2.). 